\title{
Correspondence
}

To the Editors

\section{Cutaneous manifestations among COVID-19 patients: Tip of an iceberg?}

Sri Lanka Journal of Child Health, 2020; 49(3): 310-311

http://dx.doi.org/10.4038/sljch.v49i3.9159

(Key words: COVID-19, cutaneous manifestations)

COVID-19 (SARS-CoV-2) is a pandemic declared by the World Health Organisation (WHO) on $11^{\text {th }}$ March 2020. The case definition is updated regularly following several studies reviewing clinical characteristics. The clinical spectrum has just started unfolding itself for this novel virus. It started with respiratory symptoms (fever and at least one sign/symptom of cough, shortness of breath) to which was subsequently added diarrhoea, rash, anosmia, ageusia, mental confusion, stroke, seizures, acute kidney damage, liver damage, COVID toes, multisystem inflammatory syndrome in children (MIS-C) and many more ${ }^{1}$.

We want to highlight the cutaneous manifestations among healthy young patients (mostly children and adolescents) as sole manifestations of Covid-19 as well as part of multisystem involvement. These manifestations include acute self-healing pernio (chilblain)-like acro-ischaemic lesions, in the absence of cold exposure, affecting the feet and hands, exanthematous (morbilliform) rash predominantly involving the trunk, livedo-like/ purpuric/necrotic vascular lesions, urticaria, vesicular (varicella-like) eruptions, dengue-like rashes and erythema multiforme-like lesions. They were initially reported from Italy among $20.4 \%$ of 148 COVID-19 positive patients ${ }^{2}$ and from Spain among $18 \%$ of children ( 4 of 22 ) without history of other viral infections, intake of drugs or recent immunization $^{3}$. Primarily, these cutaneous manifestations appear to be a hyper-inflammatory response to COVID virus. Histologic and immunohistochemistry studies of skin biopsies revealed a pattern of altered coagulation as complement-mediated thrombotic vasculopathy with microvascular injury ${ }^{4}$. In addition, there was co-localization of COVID-19 spike glycoproteins with $\mathrm{C} 4 \mathrm{~d}$ and $\mathrm{C} 5 \mathrm{~b}-9$ in the cutaneous microvasculature ${ }^{5}$. Most reported cases have negative COVID-19 RT PCR, and the observed skin lesions could represent late manifestations of infection, or cutaneous reactions to the numerous treatments used to treat COVID-19. At present there are no treatment guidelines for these skin lesions.

Whether any of these skin manifestations described are a clue towards Covid-19 infection among the paediatric population remains a challenge. In areas where laboratory facilities are scarce, can these findings predict any specific course/outcome of COVID-19 which could lead to early intervention and development of specific treatment guidelines? Larger studies with biopsies and tests for COVID19 virus infection are needed. We need dedicated COVID registry in all affected countries (e.g. American Academy of Dermatology available online at www.aad.org/covidregistry), in which healthcare provider can report COVID-19 symptoms. This will help frame and test new hypotheses about COVID-19. We also suggest testing for SARS-CoV-2 by RT-PCR among patients presenting with new-onset skin lesions that have no other clear cause. Those with lesions for more than 4 weeks, immunoglobulin $\mathrm{M}$ (IgM) and immunoglobulin $\mathrm{G}$ (IgG) antibody testing may be done following local guidelines ${ }^{6}$. Better understanding of cutaneous manifestations, their association with co-morbidities and treatment is the only way to handle this rapidly evolving pandemic.

\section{References}

1. World Health Organization. Coronavirus disease 2019 (COVID-19) situation report - 112.

https://www.who.int/docs/defaultsource/coronaviruse/situationreports/20200511-covid-19-sitrep112.pdf?sfvrsn $=813 \mathrm{f} 26692$ (Accessed July 20, 2020).

2. Recalcati S. Cutaneous manifestations in COVID-19: a first perspective. Journal of the European Academy of Dermatology and Venereology 2020; 34(5): $212-\mathrm{e} 213$. https://doi.org/10.1111/jdv.16387 PMid: 32215952

3. Torrelo A, Andina D, Santonja C, et al. Erythema multiforme-like lesions in children and COVID-19. Pediatric Dermatology 2020; 37(3):442-6.

https://doi.org/10.1111/pde.14246

PMid: 32445583 PMCid: PMC7283638

4. Zhang Y, Xiao M, Zhang S, Xia P, Cao W, Jiang $\mathrm{W}$, et al. Coagulopathy and antiphospholipid antibodies in patients with Covid-19. New England Journal of 
Medicine 2020; 382(17):e38.

https://doi.org/10.1056/NEJMc2007575

PMid: 32268022 PMCid: PMC7161262

5. Magro C, Mulvey JJ, Berlin D, Nuovo G, Salvatore S, Harp J, et al. Complement associated microvascular injury and thrombosis in the pathogenesis of severe COVID-19 infection: a report of five cases. Translational Research 2020; 220:1-13. https://doi.org/10.1016/j.trs1.2020.04.007 PMid: 32299776 PMCid: PMC7158248
6. Freeman EE, McMahon DE, Fitzgerald ME, et al. The American Academy of Dermatology COVID-19 registry: Crowdsourcing dermatology in the age of COVID-19. Journal of the American Academy of Dermatology 2020; 83(2):50910.

https://doi.org/10.1016/j.jaad.2020.04.045 PMid: 32305438 PMCid: PMC7162762

Mangla Sood $^{1}$, *Seema Sharma ${ }^{2}$

${ }^{1}$ Associate Professor, Department of Paediatrics, Indira Gandhi Medical College, Shimla, Himachal Pradesh, India, ${ }^{2}$ Associate Professor, Department of Paediatrics, Dr. Rajendra Prasad Government Medical College, Kangra at Tanda, Himachal Pradesh, India

*Correspondence: dr.seema73.ss@gmail.com

orcid.org/ 0000-0003-2809-9332 